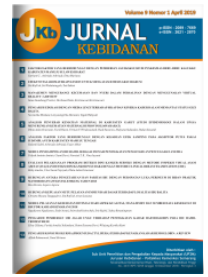

Volume 10 Nomor 1 (2020) 19-24

JURNAL KEBIDANAN

p-ISSN: 2089-7669 ; e-ISSN: 2621-2870

https://doi.org/10.31983/jkb.v10i1.5278

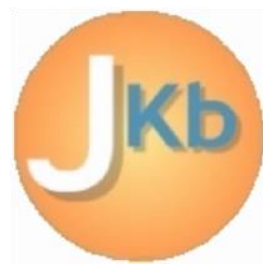

\title{
Effectiveness of Menstrual Calender Application to Adolescent Girl Behavior in District Gunung Anyar Tambak City of Surabaya
}

\author{
Desta Ayu Cahya Rosyida \\ Prodi S1 Kebidanan, Fakultas Ilmu Kesehatan,Universitas PGRI Adi Buana Surabaya \\ J1. Dukuh Menanggal XII/04 Surabaya, Jawa Timur, Indonesia \\ Corresponding author: Desta Ayu Cahya Rosyida \\ Email: desta@unipasby.ac.id
}

Received: September $27^{\text {th }}, 2020$; Revised: November $11^{\text {th }}, 2020$; Accepted: March $24^{\text {th }}, 2020$

\begin{abstract}
Out of wedlock pregnancy is an example of the lack of understanding, knowledge, attitudes and behavior regarding reproductive health. One effort to increase understanding is by introducing many ways about reproductive health, one of which is by introducing the way to know the menstrual cycle. Technological sophistication actually makes it easie for everyone to obtain information via the internet. Then anyone can actually use the application on the mobile. So the every teen can know the menstrual cycle well and know how long the menstrual cycle. The aims is Application Menstrual Calender for young women to know the regular menstrual cycle or not. It was a quantitative study using Quasi Experiment with one group comparation pretest-posttest design. A sample of 34 young women aged 1022 years and using a total sampling technique.In this design the treatment is carried out, then the conditions before and after the treatment are compared. Wilcoxon Signed Ranks Test showed that Menstrual. The average age of respondents is 17 years included in the category of late teens $(66.7 \%)$ and the average education of respondents who actively use the menstrual calendar application that is high school (100\%). Adolescent girls behavior behaves positively $(61,8 \%)$. Calendar application was effective on adolescent girls' behavior.
\end{abstract}

Keywords: application; menstrual calendar; behavior; adolescent

\section{Pendahuluan}

Jumlah remaja putri dari data kependudukan Dari Kementrian Kesehatan khususnya dalam bidang kesehatan, kesehatan reproduksi menunjukkan angka 70.250.528. Data ini adalah data semua kegiatan pembangunan kesehatan obyek khususnya yaitu remaja putri. [1]

Setiap remaja tentunya memiliki rasa ingin tahu terhadap sesuatu yang baru, contonya ingin selalu bisa mengeksplorasi dirinya dan lingkungan sekitar. Rasa ingin tahu yang berlebih jika tidak diimbangi, dan terkadang bisa mengakibatkan tindakan yang memiliki risiko yang tinggi baik bagi dirinya sendiri, orang lain, dan juga lingkungan sekitaranya.[2] Suatu tindakan yang terlepas dari pengawasan, bisa berdampak dan berisiko yang membahayakan akan menimbulkan berbagai masalah. Salah satu dari masalah tersebuat yaitu dengan kesedaran remaja putri mengenai kesehatan reproduksi.[3]

Sekarang ini banyak khasus kejadian hamil diluar nikah, hal ini dipicu dengan kurangnya pemahaman, pengetahuan, sikap, dan juga perilaku individu seseorang mengenai mentingnya menjaga kesehatan reproduksi.[4] Dampak dari pemahaman, pengetahuan dan perilaku yang kurang baik bisa secara tidak langsung merugikan bagi diri sendiri, keluarga. Masa Remaja merupakan masa yang sangat penting dan harus dalam pengawasan dan pemantauan pada saat masa perkembangannya, yang penting yaitu kognitif, 
emosi, sosial dan spiritual.[5] Salah satu upaya peningkatan pemahaman tersebut dikenalkan banyak cara tentang kesehatan reproduksi salah satunya mengenalkan cara mengetahui siklus menstruasi. [6]

Banyak remaja yang sering mensalahartikan mengenai kesehatan reproduksi, contonya masalah seksual. Edukasi dari dini secara bertahap sangat diperlukan, banyak orang tua yang masih canggung untuk mengajarkan edukasi tentang kesehtaan reproduksi, merasa topik ini sangat penting bagi remaja.[7] Membahas mengenai hubungan seksual dari ini seharusnya hal yang penting bagi orang tua dan petugas kesehatan untuk mengedukasi baik kesehatan fisik, mental, dan sosial dalam kesehatan reproduksi, sehingga remaja putri tidak salah mengartikan.[8]

Kesehatan reproduksi merupakan suatu keadaan sehat bagi remaja baik secara fisik, mental, dan sosial secara utuh. Kesehatan reproduksi juga membahas mengenai arti, sistem, fungsinya dan prosesnya.[9] Menstruasi yaitu meluruhnya sel-sel dinding rahim apabila tidak terjadi pembuahan, bisa dikatan juga perdarahan uterus yang terjadi secra periodik dan siklik. Menstruasi terjadi karena pelepasan (deskuamasi) endimetrium karena hormon ovarium (estrogen dan progesteron) mengalami penurunan terutama progesteron, pada akhir siklus ovarium. Silkus menstruasi normanya 28-31 hari lamanya 5-7 hari, kemudian masa ovulasi terjadi 14 hari setelah haid pertama.[10] Gangguan menstruasi banyak dialami oleh perempuan contonya siklus menstruasi yang tidak teratur akan mengakibatkan kekhawatiran pada diri perempuan.[11]

Berdasarkan hasil studi pendahuluan yang dilakukan pada tanggal 20 februari 2019 di kelurahan gunung anyar dari 10 orang remaja putri tidak mengerti tentang kalender menstruasi. 7 tidak mengerti sama sekali , 3 hanya pernah dengar tentang kalender menstruasi tetapi tidak paham .Sehingga banyak dari mereka yang tidak memperhatikan siklus menstruasi. Dijaman yang sekarang dengan kecanggihan teknologi sebetulnya memudahkan setiap orang untuk memperoleh informasi melalui internet, maka setiap orang sebenarnya bisa menggunakan aplikasi yang ada di handphone. sehingga setiap remaja bisa mengetahui siklus menstruasi dengan baik dan tahu berapa lama siklus menstruasinya. Maka dari itu peneliti ingin meneliti "Efektifitas Aplikasi Kalender Menstruasi terhadap Perilaku Remaja Putri di Kelurahan Gunung Anyar Surabaya.
Gambar 1.

Aplikasi Kalender Menstruasi

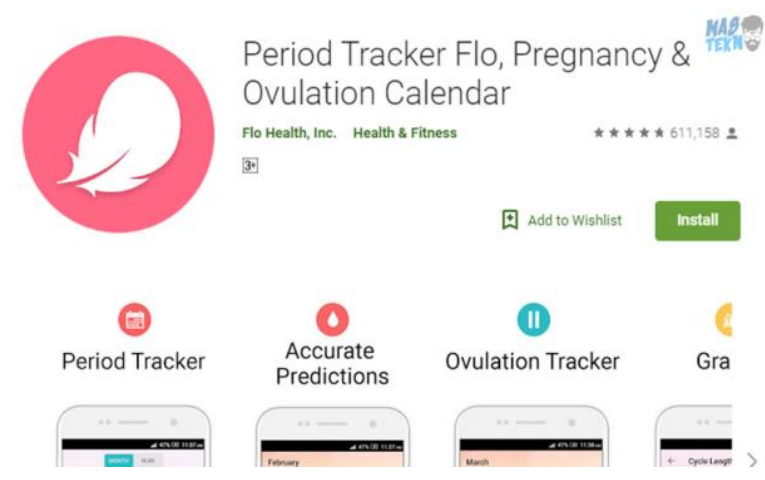

Gambar 2.

Cek masa ovulasi

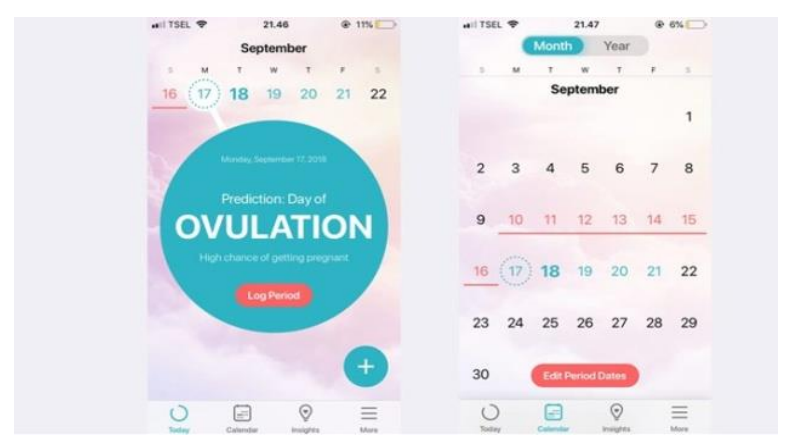

Gambar 3.

Grafik Siklus Menstruasi

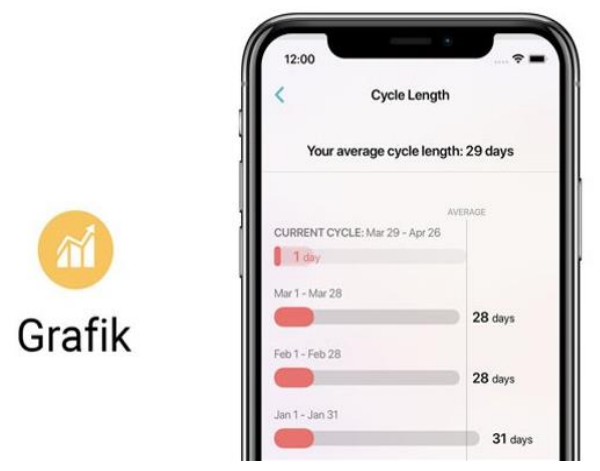

Metode Penelitian

Penelitian ini kuantitatif dengan desain penelitian (Quasi Exsperiment Design) [12], dengan rancangan yang digunakan one groups comparasion pretest-postest design. Pada desain ini dilakukan perlakuan,kemudian diperbandingkan keadaan sebelum dan sesudah dilakukan perlakuan.[13]

Penelitian ini dilakukan pada bulan Maret 2019 - April 2019 di Perumahan Wisma Indah RW 7, Kelurahan Gunung Anyar T, Kecamatan Gunung Anyar Kota Surabaya. 
Populasi pada penelitian ini adalah semua remaja putri usia 10-22 tahun di Perumahan Wisma Indah RW 7 Kelurahan Gunung Anyar , Kecamatan Gunung Anyar Kota Surabaya.

Populasi ini adalah seluruh remaja putri usia 10-22 tahun di Kelurahan Gunung Anyar Surabaya. Dari jumlah Populasi remaja putri di dapatkan sampel yaitu sebanyak 34 remaja putri. Sedangkan teknik sampling yang digunakan yaitu menggunakan total sampling. [14]

Alat ukur penelitian ini menggunakan kuesioner. Alur penelitian yaitu pertama minggu pertama siklus mestruasi pertama, para remaja putri diukur tingkat perilaku dalam pemahaman menstruasi dan kalender mestruasi dengan cara memberikan kuesioner. Kemudian setelah itu peneliti memdemonsrasikankan cara pemakaian aplikasi kalender menstruasi dari android yang dapat di digunakan oleh remaja putri ketika haid dalam 3 kali siklus menstruasi bulan kedepannya. Sebelumnya peneliti dalam mengontrol responden dengan cara memberikan lembar observasi atau lembar kendali untuk mencacat siklus haidnya teratur atau tidak. Sehingga remaja putri mengetahui dengan mudah siklus mestruasinya teratur atau tidak. Kemudian terakhir intervensi peneliti memberikan kuesioner perilaku kembali untuk melihat adakah perubahan perilaku pada remaja putri.

Pengolahan data dalam penelitian ini menggunakan Wilcoxon Signed Ranks Test yaitu salah satu jenis uji berkorelasi yang dilakukan pada dua variabel[15]. Sebelum melakukan penelitian, peneliti terlebih dahulu sudah mendapatkan persetujuan etik oleh Komisi Etik penelitian kesehatan "Health Research Ethics Committee" Poltekkes Kemenkes Semarang dengan hasil layak etik No.010/EA/KEPK/2020.

\section{Hasil dan Pembahasan}

Hasil penelitian yang telah diperoleh tentang "Efektivitas Aplikasi Kalender Menstruasi terhadap Perilaku Remaja Putri”. Penelitian ini dilakukan di Himpunan Karang Taruna di Kelurahan Gunung Anyar Kota Surabaya terhadap 34 responden remaja putri.
Tabel 1 menggambarkan karakteristik responden yang meliputi umur dan pendidikan. Hasil analisis karakteristik responden yang didapatkan rata-rata usia yang menggunakan aplikasi kalender menstruasi selama 3 kali dalam siklus menstruasi selama 3 bulan berusia 17,03 tahun yaitu masuk dalam kategori remaja akhir $66,7 \%$ berpendidikan SMP dan $100 \%$ berpendidikan SMA. Kemudian rata-rata usia yang menggunakan aplikasi kalender menstruasi 2 kali dalam 3 kali siklus menstruasi berusia 15,25 tahun yaitu masuk dalam kategori remaja menengah yang 33,3\% berpendidikan SMP.

Tabel 2 Menunjukkan bahwa 94,1\% remaja putri kurang memahami pentingnya kesehatan reproduksi, dan 5,9\% remaja putri memahami dengan baik pentingya kesehatan reproduksi, Perubahan pengetahuan negatif setelah intervensi menjadi 11 remaja putri $(32,4 \%)$ dan perubahan pengetahuan positif 23 remaja putri $(67,6 \%)$, bahwa perilaku negatif responden sebelum intervensi yaitu tidak peduli terhadap kesehatan reproduksi yaitu $100 \%$, perilaku negatif 13 remaja putri $(38,2 \%)$ dan perubahan perilaku positif 21 remaja putri $(61,8 \%)$ setelah intervensi.

Tabel 3 menunjukkan hasil uji normalitas dengan Shapiro-Wilk didapatkan hasil $\mathrm{p}<0.05$ artinya distribusi tidak normal. Hal ini bertujuan untuk menentukan analisa bivariat yang akan digunakan Wilcoxon Signed Ranks Test.

Tabel 4 Hasil uji Wilcoxon Sign Rank test menunjukkan jika ada efektifitas penggunaaan aplikasi kalender menstruasi yaitu dengan nilai $\mathrm{p}=0,000$.

Usia merupakan salah satu faktor yang mempengaruhi suatu perilaku seseorang. Semakin tua usia akan semakin meningkat pengetahuan dan perilaku seseorang. Seorang yang yang memiliki pemahaman yang lebih dewasa cenderung akan memiliki tingkat keterampilan dan kemampuan yang lebih baik dibandingkan dengan usia di bawahnya.[16] Meningkatkan usia seseorang seringkali berbanding lurus dengan pengalaman dan membaiknya kinerja individu dan usia akan mempengaruhi kondisi fisik, mental, kemampuan kerja dan tanggung jawab seseorang.[17] 
Tabel 1

Hasil Analisis Karakteristik Responden di Kelurahan Gunung Anyar Kota Surabaya 2019 (n=34).

\begin{tabular}{lcc}
\multicolumn{1}{c}{$\begin{array}{c}\text { Karakteristik } \\
(\mathbf{n}=\mathbf{3 4})\end{array}$} & 3 kali & Perlakuan \\
\cline { 2 - 3 } & & 2 kali \\
\hline Umur Remaja Putri & 17,03 & 15,25 \\
\hline Mean \pm SD & 17,00 & 15,50 \\
Median & $14 \pm 19$ & $14 \pm 16$ \\
Min \pm max & & \\
\hline Pendidikan & $66,7 \%$ & $33,3 \%$ \\
SMP & $100 \%$ & $0 \%$ \\
SMA & & \\
\hline
\end{tabular}

Tabel 2.

Tingkat Pengetahuan dan Perilaku Sebelum dan Sesudah dilakukan Intervensi pada Responden di Kelurahan Gunung Anyar Kota Surabaya 2019 (n=34)

\begin{tabular}{lccc}
\hline & $\begin{array}{c}\text { Pengetahuan } \\
\text { Sebelum Intervensi }\end{array}$ & Frekuensi & Presentase (\%) \\
\hline Kurang & & 32 & 94,1 \\
Baik & Pengetahuan & 2 & 5,9 \\
\hline & Setelah Intervensi & Frekuensi & Presentase (\%) \\
\multicolumn{2}{c}{ Kurang } & & \\
Baik & 11 & 32,4 \\
\hline \multicolumn{2}{c}{ Perilaku Sebelum Intervensi } & Frekuensi & 67,6 \\
\hline Negatif & 34 & Presentase (\%) \\
Positif & 0 & 100 \\
\hline \multicolumn{2}{c}{ Perilaku Setelah Intervensi } & Frekuensi & 0 \\
\hline Perilaku Negatif & 13 & Presentase (\%) \\
Perilaku Positif & 21 & 38,2 \\
\hline \multicolumn{2}{c}{ Total } & $\mathbf{3 4}$ & 61,8 \\
\hline
\end{tabular}

Tabel 3

Hasil Uji Normalitas

\begin{tabular}{cccc}
\hline Variabel $(\mathbf{n}=\mathbf{3 4})$ & t-statistik & Sig & ket \\
\hline Pengetahuan Pre & 0,944 & 0,083 & Normal \\
Prilaku Pre & 0,894 & 0,003 & Tidak normal \\
Pengetahuan Post & 0,642 & 0,000 & Tidak normal \\
Prilaku Post & 0,691 & 0,000 & Tidak normal \\
\hline
\end{tabular}

\section{Tabel 4}

Tabel Efektifitas Perubahan Pengetahuan dan Perilaku Responden di Kelurahan Gunung Anyar Kota Surabaya $2019(\mathrm{n}=34)$.

\begin{tabular}{lc}
\multicolumn{1}{c}{ Variabel $(\mathbf{n}=\mathbf{3 4})$} & P Value $\boldsymbol{\alpha}=\mathbf{0 , 0 5}$ \\
\hline Pengetahuan Pre-Pengetahuan Post & 0,000 \\
Perilaku Pre-Perilaku Post & 0,000 \\
\hline
\end{tabular}

Responden pada penelitiaan ini rata-rata remaja akhir 17 tahun yang duduk di bangku SMA yang kematangannya sudah terbentuk untuk mengambil keputusan dan pemahaman mengenai aplikasi kalender mentruasi. Piaget mengemukakan jika proses belajar seseorang harus sesuai dengan tahap perkembangan kognitif.[19] Sebagaimana kualitas kesehatan reproduksi setiap perempuan sangan dibutuhkan dalam menjaga dan meningkatkan kualitas hidup perempuan, bahwa semakin bertambahnya usia secara tidak langsung akan menambah pengetahuan dan juga perilaku yang baik karena dalam mencerna informasi juga 
semakin baik kesehatan reproduksi seseorang remaja.[20]

Karakteristik responden yang berkaitan dengan pendidikan akan berhubungan langsung dengan pemberdayaan individu untuk meningkatkan pengetahuan dan juga meningkatkan perilaku yang baik. Seseorang yang memiliki pengetahuan yang lebih makan cara menyerap informasi juga akan semakin baik dan juga bisa mengembangkan pola pikirnya khususnya mengenai pentingnya kita menjaga kesehatan reproduksi.

Sumber Informasi juga berkaitan erat dengan tingkat pendidikan formal seseorang.[21] Daya serap informasi yang diterima setiap individu akan dipengaruhi oleh tingkat pendidikan seseorang, seseorang yang lebih baik menerima dan mennagkan informasi secara tidak langsung pasti berpendidikan tinggi, hal tersebut sejalan dengan penelitian mengenai gambaran pengetahuan dan perilaku remaja mengenai pemeriksaan kesehatan reproduksi di kelurahan Petisah Tengah Sumatra Utara, diperoleh bahwa responden yang mempunyai pendidikan tinggi mempunyai pemahaman yang lebih baik tentang kesehatan reproduksi.[22] Dengan kata lain tingkat pendidikan seseorang sangat mempengaruhi tingan pengetahuan, Suatu identitas seseorang dapat dinilai dengan tengkat pendidikan dan seberama poses belajar seseorang tersebut dengan diharapkan akan menghasilkan pola pikir yang baik pula. Penelitian lain yang bertujuan untuk mengetahui pendidikan terhadap pengetahuan dan perilaku remaja dalam masalah kesehatan reproduksi didapatkan hasil bahwa terdapat hubungan antara tingkat pendidikan remaja terhadap pengetahuan dan perilaku remaja mengenai masalah kesehatan reproduksi.[23]

Hasil analisis bivariat menunjukkan bahwa ada efektifitas aplikasi kalender menstruasi terhadap perilaku remaja putri. Dalam penelitian ini ada perubahan pengetahuan baik dan perilaku sebelum dan sesudah dilakukan intervensi, yaitu pemahaman remaja mengenai menstruasi dan kesehatan reproduksi lebih baik.

Penelitian ini menunjukkan bahwa terdapat perubahan pengetahuan pada responden yaitu Perubahan pengetahuan kurang 11 remaja putri $(32,4 \%)$ dan perubahan pengetahuan baik 23 remaja putri $(67,6 \%)$. Pada perilaku terdapat perubahan perilaku pada responden yaitu perilaku kurang 13 remaja putri $(38,2 \%)$ dan perubahan perilaku baik 21 remaja putri $(61,8 \%)$. Hasil analisis bivariat dengan Wilcoxon Signed Ranks
Test menunjukkan Aplikasi Kalender Menstruasi efektif dengan nilai $\mathrm{p}=0,000$ terhadap perilaku remaja putri.

Pengetahuan dan perilaku yang kurang pada remaja putri disebabkan karena kepatuhan remaja putri dalam menggunakan aplikasi kalender menstruasi yang kurang sehingga mereka tidak mengetahui apakah siklus mestruasinya teratur atau tidak. Dalam ketidaktahuannya ini bisa mengakibatkan kurang pahamnya mengenai pentingnya kesehatan reproduksi. Jika remaja putri masing-masing individu mengetahui dan paham mengnai hal tersebut maka akan mempermudah mengetahui indikasi patologis jika siklus mentruasinya tidak teratur kemudian segera memeriksakan ke petugas kesehatan. Sedangkan Pengetahuan dan perilaku remaja putri yang baik yaitu mereka sudah memahami dan mematuhi penggunaan aplikasi kalender menstruasi dengan baik, sehingga mereka bisa mengetahui siklus mestruasinya teratur atau tidan dan juga memahami pentingnya menjaga kesehatan reproduksi dengan mematuhi pada setiap bulannya merekan menggunakan aplikasi tersebut.

Hasil penelitian ini menunjukkan bahwa aplikasi kaleder menstruasi efektif terhadap perilaku remaja putri sehingga dapat menjadi wacana baru untuk meningkatkan perilaku sehat remaja dalam deteksi dini adanya kelainan kelainan kesehatan reproduksi.

Saran untuk penelitian selanjutnya penelitian ini dilakukan menggunakan aplikasi kalender mentruasi yang sudah ada pada Android, kedepannya peneliti akan melakukan penelitian dengan membuat aplikasi kalender menstruasi yang akan menerapkan system penanganan atau solusi masalah dalam kesehatan reproduksi.

\section{Simpulan}

Simpulan penelitian ini adalah adanya perubahan pengetahuan dan perilaku responden setelah diberikan edukasi penggunakan Aplikasi Kalender Menstruasi. Hasil uji analisis menunjukkan jika Aplikasi Kalender menstruasi Efektif terhadap perilaku remaja putri dengan nilai $\mathrm{p}=0,000$.

Sebaiknya bidan meningkatkan kualitas KIE dan penyuluhan kepada remaja putri pentingnya kesehatan reproduksi. Sebaikanya peneliti lebih mengembangkan metode penyuluhan pemberian informasi dan edukasi mengenai penanganan adanya tanda dan gejala patologis. 


\section{Ucapan Terimakasih}

Peneliti mengucapkan terimakasih pada Lembaga LPPM Universitas PGRI Adi Buana surabaya yang memberi dana hibah kepada peneliti dan peneliti juga mengucapkan terimakasih untuk bimbingannya sehingga diberikan ijin untuk meneliti berkaitan dengan kesehatan reproduksi pada remaja putri. Dan tidak lupa juga kami ucapkan terimakasih kepada semua pihak yang ikut membantu dalam penelitian ini sehingga peneliti mampu menyelesaikan penelitian ini dengan lancar dan bisa bermanfaat bagi para remaja putri kususnya mengenai pentingnya mengetahui siklus menstruasi dengan menggunakan metodel Aplikasi Kalender Menstruasi.

\section{Daftar Pustaka}

[1] Depkes Jatim. (2014). Pendidikan Kesehatan Reproduksi Remaja. Surabaya: Jatim dalam angka.

[2] Anonim. (2009). Remaja Indonesia masih sangat membutuhkan informasi kesehatan reproduksi.

http://scbsradio.co.cc/2009/02/remajaindonesia-masih-sangat-membutuhkaninformasi-kesehatan-reproduksi/[online][20 April 2019].

[3] Almawaliy, H. (2010). Opini Edisi 30: Kesehatan Reproduksi bagi Remaja http://www.rahima.or.id/index,php?option= com_content\&view=article\&id551:opiniedisi-30-kesehatan-reproduksi-bagi remaja\&catid $=33$ :opini-suararahima\&Itemid=305 [online 20 April 2019].

[4] Sarwono. (2014). Ilmu Kebidanan Sarwono Prawirohardjo. Jakarta: PT. Bina Pustaka Sarwono Prawirohardjo.

[5] Susanti. (2014). Sistem Informasi Inventori Obat Pada Rumah Sakit Umum Daerah Padang, Volume 16, No1.

[6] BKKBN. (2015). Pedoman Pengelolaan Pusat Informasi dan Konseling Remaja dan Mahasiswa. Jakarta: Derektorat Bina Kesehatan Remaja.

[7] Ali Imron. (2012). Pendidikan Kesehatan Reproduksi Remaja. Yogyakarta: Ar-Ruzz Media.

[8] Arulkumaran S, Regan L, Papageorghiou A. (2011). Oford Desk Reference Obstetrics and Gynecology. New York: Oxford University Press.
[9] Prawirohardjo, Sarwono. (2014). Ilmu Kebidanan Sarwono Prawirohardjo. Jakarta: PT. Bina Pustaka Sarwono Prawirohardjo

[10] Kusmiran, E. (2012). Kesehatan Reproduksi Remaja dan Wanita. Jakarta: Salemba Medik.

[11] Kollman, N. (1998). Kesehatan Reproduksi Remaja. Jakarta: Lembaga Konsumen Indonesia

[12] Dahlan. (2013). Besar Sampel dan Cara Pengambilan Sampel. Jakarta: Salemba Medika.

[13] Sugiyono. (2014). Metode Penelitian Kuantitatif Kualitatif dan R\&D. Bandung: Alfabeta.

[14] Arikunto, Suharsimi. (2010). Prosedur Penelitian: Suatu Pendekatan Praktik. Jakarta: PT Rineka Cipta

[15] Sugiyono. (2013). Statistika untuk Penelitian. Bandung: Alfabeta.

[16] Soeprihanto, J. (2011). Penilaian Kinerja dan Pengembangan Karyawan. Yogyakarta: BPFE.

[17] Hasibun.(2015). Manajemen Sumber Daya. Edisi Revisi. Jakarta: Bumi Aksara.

[18] Pangesti, Nova Ari dan Cokroaminoto, Nurlaila. (2012). Gambaran Karakteristik Wanita Usia Subur Yang Melakukan Pemeriksaan Inspeksi Visual Asam Asetat (IVA) di Puskesmas Kranganyar. Jurnal Ilmiah Kesehata Keperawatan.

[19] Suciati. (2015). Teori belajar dan motivasi. Dirjen Dikti Departemen Nasional.

[20] Siagian .(2011). Manajemen sumber daya manusia. Jakarta: Bina.

[21] Desmita. (2015). Karakteristik dan persepsi penelitian terhadap sumber daya perpustakaan dan hubungannya dengan pemanfaatan koleksi. http//www.pustakadeptan.go.idpublicationpp14105.pdf.

diunduh 13 Juni 2019

[22] Octavia. (2017). Gambaran pengetahuan ibu mengenai pemeriksaan papsmear di kelurahan petisah tengah. Fakultas Kedokteran Universitas Sumatra Utara Medan. digilib. Diunduh tanggal 28 Juni 2019.

[23] Imelda. (2011). Psikologi Perkembangan. Jakarta: Kencana. 